*Pós-doutorandodaUniversidade Estadual do Norte do Paraná (UENP). Doutor em Direito do Estado pela Pontifícia Universidade Católica de São Paulo (PUCSP). Professor de Graduação e Pós-graduação (Mestrado) em Direito da Universidade Metodista de Piracicaba (UNIMEP). Professor de Graduação em Direito do Centro Universitário Adventista de São Paulo (UNASP). Promotor de Justiça do Ministério Público do Estado de São Paulo Aposentado. Advogado.

E-mail: jaremedio@yahoo.com.br

$\begin{array}{lr}\text { ** Mestre em } & \text { Direito pela } \\ \text { Universidade } & \text { Metodista } \\ \text { de Piracicaba } & \text { (UNIMEP). } \\ \text { Advogado.E-mail: } & \text { ga_silva01@ } \\ \text { hotmail.com } & \end{array}$

\section{A Amplitude Do Conceito De Cidadania Para Efeito De Propositura da Ação Popular}

\author{
The Extent Of The Concept of Citizenship Regarding \\ The Use Of Popular Action Lawsuits
}

\author{
José Antônio Remedio* \\ Gabriel Silva Aranjues **
}

Como citar: REMEDIO, José Antônio; ARANJUES, Gabriel Silva. A amplitude do conceito de cidadania para efeito de propositura da ação popular. Revista do Direito Público, Londrina, v. 14, n. 3, p. 184-200, dez. 2019. DOI: 10.5433/24157-108104-1.2019v14n3p. 184. ISSN: 1980-511X

Resumo: A pesquisa tem por objeto analisar o conceito de cidadania para fins de ajuizamento da ação popular. Como instrumento de controle da Administração Pública, a ação popular pode ser proposta por qualquer cidadão. A ação encontra-se prevista no inciso LXXIII do artigo $5^{\circ}$ da Constituição Federal e está disciplinada pela Lei 4.717/65. O $\S 3^{\circ}$ do artigo $1^{\circ}$ da Lei 4.717/65 estatui que o autor precisa comprovar sua condição de cidadão para ajuizar a ação popular, por meio de seu título de eleitor ou de documento equivalente. A exigência prevista na Lei 4.717/65 restringe o conceito de cidadão, ao limitar o uso da ação popular exclusivamente às pessoas detentoras de direitos políticos demonstráveis através do título de eleitor ou de documento equivalente. Conclui a pesquisa que o conceito de cidadania abrange na atualidade não só os direitos políticos, mas também os direitos sociais e civis, motivo por que o termo cidadão, para fins de ajuizamento da ação popular, deve ser amplo, não se limitando aos contornos estabelecidos pela Lei 4.717/65, que nesse aspecto não foi recepcionada pela Constituição Federal. $\mathrm{O}$ método utilizado é o hipotético-dedutivo, com base em pesquisa doutrinária e jurisprudencial.

Palavras-chave: Ação popular. Amplitude do conceito de cidadania. Cidadania. Cidadão. Legitimidade ativa.

Abstract: The objective of this research is to analyze the concept of citizenship for the purpose of filing popular action lawsuits. 
As an instrument of control of the Public Administration, the popular action lawsuit can be proposed by any citizen, which is legitimized by LXXIII of article 5 of the Brazilian Federal Constitution and is disciplined by Law n. 4717/65. Moreover, paragraph 3 of article 1 of Law n. 4717/65 states that the plaintiff must prove his status as a citizen in order to file the popular action lawsuit, by means of his voter registration or equivalent document. The requirement set forth by Law 4717/65 restricts the concept of citizen, by limiting its use exclusively to people with demonstrable political rights through their voter ID or equivalent documents. This study concludes that the concept of citizenship currently covers not only political rights, but also social and civil rights, which is why the term citizen, for purposes of filing the popular action lawsuit, must be broad, not limited to the contours established by Law 4.717/65, which in this aspect is not included in the Federal Constitution. This paper utilized the hypotheticaldeductive method with literature review.

Keywords: Popular action lawsuit; Extent of the concept of citizenship; Citizenship; Citizen; Legal capacity to sue. 


\section{INTRODUÇÃO}

A ação popular insere-se entre os instrumentos jurídicos de controle dos atos da Administração Pública. Prevista no inciso LXXIII do art. $5^{\circ}$ da Constituição Federal de 1988, a ação pode ser proposta por qualquer cidadão, objetivando anular de ato lesivo ao patrimônio público ou de entidade de que o Estado participe, à moralidade administrativa, ao meio ambiente $\mathrm{e}$ ao patrimônio histórico e cultural. No âmbito infraconstitucional, a ação popular está disciplinada pela Lei $4.717 / 65$.

Todavia, embora identificando-se como importante instrumento de controle da Administração Pública, a Lei 4.717/65, ao vincular o uso da ação popular a questões eminentemente políticas, restringe o conceito de cidadania ao pleno gozo de direitos políticos, limitando assim os legitimados ativos para o exercício da ação.

Ou seja, ao disciplinar a legitimidade ativa para propositura da ação popular prevista na Constituição Federal como garantia fundamental, a Lei 4.717/65 criou uma limitação à defesa dos ideais democráticos que deveriam permear o instituto, pois, conforme disposto no $\S 3^{\circ}$ do art. $1^{\circ}$ da Lei 4.717/65, tem-se como cidadão, para fins de ajuizamento da ação, apenas o indivíduo que vota e pode ser votado, ou seja, o detentor de direitos políticos, elemento esse demonstrável através da apresentação de título de eleitor ou de documento equivalente.

Sob a ótica do Estado Democrático de Direito introduzido pela Constituição Federal de 1988, constata-se que a Lei 4.717/65 inibe a amplitude da garantia constitucional ao vincular o conceito de cidadania e de cidadão exclusivamente aos direitos políticos.

É bem verdade que a evolução contemporânea do Direito traduz os direitos políticos como uma ramificação do exercício da cidadania. Porém, tais expressões não são sinônimas, haja vista que os direitos sociais e civis também integram o novo e mais abrangente conceito de cidadania.

É necessário, pois, que a doutrina e a jurisprudência venham a acolher e a sedimentar a nova e ampla concepção de cidadania, em especial para efeito de legitimidade ativa para ajuizamento da ação popular.

O estudo tem por finalidade confrontar o entendimento majoritário da jurisprudência, que acata a definição limitativa dada ao conceito de cidadão pela Lei 4.717/65, com o texto expresso na Constituição Federal vigente, objetivando verificar se o $\S 3^{\circ}$ do art. $1^{\circ}$ da Lei 4.717/65 foi recepcionado pela Lei Maior.

Estruturalmente, realizar-se-á inicialmente uma abordagem histórica sobre a origem e evolução do conceito de cidadania, com ênfase à sua existência na Grécia e Roma antigas. A seguir, abordar-se-á a cidadania na Idade Média e Contemporânea. Na sequência, tratar-se-á da legitimidade ativa para propositura da ação popular no Brasil. Em seguida, proceder-se-á à análise do inciso LXXIII do art. $5^{\circ}$ da Constituição Federal e do $\S 3^{\circ}$ do art. $1^{\circ}$ da Lei 4.717/65, objetivando materializar a não compatibilidade do dispositivo infraconstitucional com o dispositivo constitucional.

Tem-se, como hipótese, que a Constituição Federal de 1988, ao prever a legitimidade ativa 
do cidadão para ajuizar a ação popular, não limita o sentido o termo cidadão apenas aos detentores de direitos políticos, ou seja, do direito de votar e de ser votado, tendo o texto constitucional amplitude maior do que a prevista no $\S 3^{\circ}$ do art. $1^{\circ}$ da Lei $4.717 / 65$, de forma que é inconstitucional o referido dispositivo normativo infraconstitucional.

O método utilizado é o hipotético-dedutivo, com características comuns aos métodos indutivo e dedutivo, tendo como base a pesquisa descritiva e usando como procedimentos instrumentais a análise doutrinária, que dá fundamento a uma pesquisa de diagnóstico, e as análises legislativa e jurisprudencial, que permitem a pesquisa no campo empírico.

\section{A CIDADANIA NA GRÉCIA E ROMA ANTIGAS}

A cidadania, juntamente com a ética, a justiça, a moral e o direito, embora tenha surgido como instituto há cerca de 2.500 anos na Grécia Antiga, ainda hoje está envolta em conceitos bastante díspares e abrangentes.

A dificuldade em apresentar um conceito completo sobre a cidadania está envolta em vários fatores, como o fato de ser ela encarada sob concepções diferentes de sociedade para sociedade, que se alteram em decorrência do regime político adotado, costumes e tradições do povo, bem como o fato relacionado às profundas alterações perpetradas sobre o termo no decorrer da história.

É possível dividir a filosofia grega em dois momentos distintos, o primeiro anterior a Sócrates, quando houve a preocupação de buscar respostas a questões, muitas das quais até hoje permanecem em aberto, como a criação do universo e de tudo que nele existe, e o segundo, pós Sócrates, com foco em pensamentos e teorias com contextos humanos, sociais e morais.

A ideia de cidadania nasce conjuntamente com a democracia grega, instituto antigo que surgiu após o período arcaico, no qual predominaram as Oligarquias e Aristocracias, datado de aproximadamente dois mil e quinhentos anos, originário da polis grega, por volta dos séculos VI e V a.C. (CORRALO, 2016, p. 423).

Drácon, estadista da cidade grega de Atenas, foi o responsável pelos primeiros fragmentos democráticos no século VII a.C., ao estabelecer e indicar homens livres para elaborar leis. Foi autor de leis contra o homicídio, proibiu a prática de atos vingativos entre famílias, publicou normas com princípios de solidariedade e fez leis que conferiam direitos iguais a todos os cidadãos da polis (FIGUEIRA, 2001, p. 44).

Conforme Pedro Paulo Funari (2002, p. 19), a polis grega classificava-se como um Estado soberano composto pelo povo que a integrava, dividindo-se em várias tribos, que se subdividiam em fátrias, e estas em clãs (pai, mãe e filhos). As pessoas que não faziam parte destes grupos eram consideradas estrangeiras, não lhes cabendo direitos, proteção ou mesmo participação na vida política da polis, o que era deferido àqueles que fossem considerados cidadãos.

Todavia, embora todos os cidadãos tivessem o poder da palavra nas assembleias públicas gregas, na prática eram os líderes a falar, pois o povo soberano se reduzia de fato a uma minoria de 
cidadãos que tinha possibilidade de assistir regularmente às sessões, dirigidas por alguns homens mais influentes.

A influência dos homens que não dominavam a arte da oratória foi o embrião para o desenvolvimento da espécie denominada democracia representativa e para o surgimento de alianças baseadas em interesses comuns que culminaram nos partidos políticos como conhecidos hoje.

Os veredictos assinalados pelos cidadãos atenienses eram soberanos, submetendo-se somente às leis, que se dividiam em: leis divinas (themis), resultado da tradição e que não podiam ser alteradas pela vontade humana (como a proibição de matar os próprios pais ou casar-se com os familiares em primeiro grau, como os irmãos); e leis elaboradas pelos homens, que todos conheciam e eram reproduzidas por escrito em inscrições monumentais para que todos pudessem ver. As leis atenienses, uma vez aprovadas, aplicavam-se indistintamente a todos, cidadãos ou não, sendo que aqueles que haviam votado contra sua aprovação podiam deixar a cidade. A lei era chamada de nomos, conceito tão essencial que ainda perdura na atualidade, sendo, inclusive, utilizado em muitas palavras, como em relação à palavra economia). A lei humana, racional, tem uma lógica própria e pode ser modificada pela decisão racional das pessoas (FUNARI, 2002, p. 28).

Com o nascimento da democracia na Grécia Antiga, a vontade da maioria dos cidadãos imperava, não pela força ou qualquer outro método que poderia remeter às monarquias ou períodos marcados pela escravidão, mas pela deliberação racional, segundo as leis vigentes, expressada pelos responsáveis pela condução política da polis.

Convém ressaltar que a democracia grega não possuía um conceito abrangente, pelo contrário, era aplicado de maneira restrita, tanto que escravos, estrangeiros e mesmo as mulheres e crianças atenienses não tinham qualquer direito político, de forma que, para eles, a democracia não trazia qualquer vantagem.

Fato é que nem todos os cidadãos participavam das reuniões públicas que se realizavam na Ágora, tanto que a partir de 395 a.C., os cidadãos que participavam das assembleias públicas recebiam valor em dinheiro pela participação, na expectativa de que os cidadãos menos favorecidos, que dependiam do trabalho para garantir seu sustento e de sua família, pudessem participar das reuniões e usufruir dos direitos políticos do mesmo modo que os mais abastados (FUNARI, 2002, p. 29).

Este modelo que remunera cidadãos para exercerem o poder político é totalmente inviável nos Estados modernos, pois, além dos vultuosos valores que seriam despendidos para sua implementação, só seria possível em Estados bastante pequenos e com recursos econômicos expressivos.

A democracia ateniense, que se restringia à participação na vida política da polis, estava assentada em dois princípios fundamentais: a igualdade política e a liberdade.

Na lição de Aristóteles (2007, p. 155), conforme a própria lei, o pobre não tinha mais direitos que os ricos, e também os ricos não eram senhores dos pobres, pois, se assim fosse, estarse-ia diante de uma Oligarquia ou de modelos análogos à escravidão. Ao contrário, todos eram iguais. Ao considerar a liberdade e a igualdade princípios fundamentais da democracia, elas só 
podiam existir na plenitude se todos os cidadãos usufruíssem da perfeita igualdade política.

$\mathrm{Na}$ Roma Antiga, por sua vez, não havia democracia, mas um Império muito vasto e poderoso, fundamentado numa filosofia de invasão e domínio de outros territórios e povos. Com a invasão e declínio da Grécia, os romanos se apossaram de diversos institutos e conceitos helênicos, principalmente nos campos da política, religião, cultura e biologia.

Havia grande similaridade entre os conceitos de cidadania na Grécia e em Roma. Todavia, o conceito romano era mais amplo e flexível que o grego, pois escravos alforriados, aliados e até mesmo comunidades inteiras recebiam a qualidade de cidadão, o que levou historiadores a afirmarem que esta incorporação resultou no dinamismo romano, povo cada vez mais numeroso em decorrência da expansão do Império (FUNARI, 2002, p. 69).

A República Romana estava socialmente dividida em nobreza, clientes e plebe. Nos primeiros anos da República, os patrícios eram os detentores de todos os direitos políticos e somente esta classe podia ocupar cargos políticos, constituindo uma verdadeira aristocracia, que se legitimava na posse e exploração da terra, trabalhada por camponeses (FUNARI, 2002, p. 67-68).

Todavia, a realidade social que imperava no Império Romano não satisfazia os plebeus, que após começarem a prosperar exercendo atividades comerciais, empreenderam severa batalha contra os patrícios pela igualdade de direitos políticos.

Segundo Thomas Marky (1995, p. 34), a cidadania romana adquiria-se por nascimento de justas núpcias ou mesmo fora delas, caso a mãe fosse cidadã quando do parto. Ainda, "os filhos nascidos de matrimônio misto (isto é, em que um dos cônjuges fosse estrangeiro) seguiam a condição de estrangeiro, de acordo com as disposições da Lei Minicia", porém, os provincianos que serviam no exército tornavam-se cidadãos após serem liberados do serviço militar.

Em Roma, o termo cidadania indicava um liame entre o Estado e o indivíduo, isto é, os conceitos de cidadania, cidade e Estado eram conceitos próximos. Portanto, o conjunto de cidadãos romanos, após receber uma conceituação mais ampla, passou a significar o próprio Estado romano. Logo, a qualidade de cidadão avança em relação ao que se conhecia na Grécia Antiga, deixando de se restringir aos detentores de direitos políticos e passando a também abranger a titularidade de direitos públicos (DALLARI, 2013, p. 101-102).

\section{A CIDADANIA NA IDADE MÉDIA E CONTEMPORÂNEA}

Como visto, o conceito de cidadania na Grécia Antiga restringia-se ao gozo de direitos políticos, enquanto em Roma houve perceptível ampliação do conceito, que passou a abranger também a titularidade de direitos públicos.

A sociedade política da Idade Média, período histórico que se estendeu entre os anos 476 e 1.453, foi marcada pelo cristianismo, com aspiração à universalidade, pelas invasões dos bárbaros, que acarretou profundas transformações na ordem estabelecida, e pelo feudalismo, com a vida social dependendo da propriedade ou da posse da terra (DALLARI, 2013, p. 70).

$\mathrm{Na}$ Idade Média houve a centralização do poder nas mãos do rei, que era o proprietário 
das terras na qual o povo se instalava mediante o pagamento de impostos. Logo, não havia coisa pública, muito menos reuniões públicas para discussão dos rumos políticos da cidade, uma vez que tudo pertencia ao rei e tudo era decidido pelo monarca, não havendo que se falar minimamente em cidadania (ATALIBA, 1985, p. 111).

A instabilidade política, econômica e social que marcaram o período medieval inviabilizou a existência e aplicação da ação popular nos moldes do Direito Romano, uma vez que nesse período, como regra, não existia a coisa pública.

É bem verdade que alguns autores, conforme referência de Paulo Barbosa de Campos Filho (1968, p. 11), sustentam minoritariamente que as ações populares advindas do Direito Romano jamais deixaram de existir no campo do direito.

A Idade Moderna, que se iniciou em 1.453, com a tomada de Constantinopla pelos turcos, e perdurou até 1.789, com a Revolução Francesa, é marcada por um modelo de Estado absolutista, tendo como principais características a soberania e a centralização e supremacia do poder.

O conceito de cidadania ressurge na Idade Contemporânea, a partir da Revolução Francesa de 1789, movimento que foi fundamental para o surgimento do Estado de Direito, passando-se a se designar cidadania o conjunto de membros da sociedade que têm direitos e decidem o destino do Estado.

Embora o movimento revolucionário francês de 1789 tenha contribuído imensamente para a nova perspectiva da cidadania, José Afonso da Silva (1999) afirma que havia na Declaração dos Direitos do Homem e do Cidadão, inspirada nos ideais iluministas, distinção entre os conceitos de homem e de cidadão. Segundo Silva (1999, p. 10, grifo do autor):

O primeiro aspecto que nos chama a atenção no seu conceito é o da cisão que o discurso jurídico burguês fez entre o "homem" e o "cidadão", que refletiu na famosa Declaração de Direitos de 1789, que se chamou Declaração dos Direitos do Homem e do Cidadão, na qual a expressão Direitos do Homem denota o conjunto dos direitos individuais, pois ela é profundamente individualista, assinalando à sociedade um fim que é o de servir aos indivíduos, enquanto a expressão Direitos do Cidadão significa o conjunto dos direitos políticos de votar e ser votado, como institutos essenciais à democracia representativa. E esta foi a primeira manifestação da cidadania que qualifica os participantes da vida do Estado - o Cidadão, indivíduo dotado do direito de votar e ser votado -, oposta à ideia de vassalagem tanto quanto a de soberania aparece em oposição à de suserania.

Portanto, não obstante o homem a que se refere a Declaração dos Direitos do Homem e do Cidadão ser o próprio cidadão francês, havia pequenas barreiras para sua plena conceituação, herança do tempo em que a cidadania resumia-se aos direitos políticos.

Fixadas estas premissas, pode-se estabelecer que a cidadania, na órbita da democracia moderna, pode ser tomada em dois sentidos, ou seja, o sentido restrito ou técnico, e o sentido amplo, com o abandono da concepção exclusiva de direitos políticos, que sob a nova ótica seria apenas um fragmento da cidadania. 
No sentido restrito ou técnico, cidadania nada mais é que o exercício de direitos políticos, ou seja, a possibilidade de votar e ser votado, basicamente como se vislumbrava quando de seu nascedouro na Grécia Antiga.

O sentido amplo, como a própria terminologia induz, amplia o sentindo de cidadania, concebendo a ideia de titularidade de outras prerrogativas constitucionais além dos direitos políticos, tais como os direitos civis e sociais, que surgiram como consectário lógico do Estado Democrático de Direito (SIQUEIRA JÚNIOR; OLIVEIRA, 2009, p. 242).

De acordo com Thomas Humphrey Marshall (1988, p. 9), os direitos civis se compõem das garantias e liberdades individuais; os direitos sociais comunicam-se com o princípio da dignidade da pessoa humana, pois implicam nas condições mínimas necessárias para a vida digna, tudo o que vai desde o direito a um mínimo de bem-estar econômico e segurança, ao direito de participar, por completo, da herança social; os direitos políticos se referem não só à possibilidade de votar e ser votado, mas também à capacidade de fundar partidos políticos.

Em relação ao Estado Brasileiro, a democracia que se estabeleceu após a Ditadura de 1964 é bastante recente e possui especificidades quando comparada ao instituto existente em outros Estados, o que implica em características próprias inerentes à cidadania brasileira.

No período ditatorial brasileiro iniciado em 1964 tinha-se a cidadania regulada, que pode ser caracterizada "pelo controle das instituições sociais, por limites institucionais e burocráticos do sistema político democrático, pela exclusão dos sujeitos sociais e a incorporação fragmentada das reivindicações populares, aliada à estratégia do controle social” (SAMPAIO, 2008, p. 164).

A Constituição Federal de 1988, intitulada Constituição-Cidadã, rompeu as amarras da ditadura implantada em 1964, passando a adotar um conceito mais amplo e abrangente de cidadania.

Indubitavelmente, na democracia brasileira observa-se a existência de campo fértil para o desenvolvimento da ideia de cidadania. Nesse sentido, de acordo com José Afonso da Silva (1999, p.10):

Uma ideia essencial do conceito de cidadania consiste na sua vinculação com o princípio democrático. Por isso, pode-se afirmar que, sendo a democracia um conceito histórico que evolui e se enriquece com o evolver dos tempos, assim também a cidadania ganha novos contornos com a evolução democrática. É por essa razão que se pode dizer que a cidadania é o foco para onde converge a soberania popular.

Na Constituição Federal de 1988, o termo cidadania é citado sete vezes, enquanto o termo cidadão é referido trezes vezes. Tal constatação moveu José Afonso da Silva (1999, p. 11) a verificar se no texto constitucional os atos de cidadania estão restritos aos direitos políticos ou se há um conceito mais expansivo. E a conclusão é no sentido de que a cidadania disciplinada na Constituição Federal é termo muito mais amplo do que o relacionado ao titular de direitos políticos, pois reconhece os integrantes do povo como indivíduos que integram a sociedade estatal (art. 52, 
LXXVII). Também, pela leitura do texto constitucional, verifica-se que no Estado Democrático de Direito o próprio Estado está submetido à vontade popular, e neste contexto o termo vincula-se ao conceito de soberania popular (parágrafo único do art. 12), com os direitos políticos (art. 14), com o conceito de dignidade da pessoa humana (arts. 12 e 111), bem como com os objetivos da educação (art. 205) como base e meta essenciais do regime democrático.

A cidadania é conceituada por Elias Farah $(2001$, p. 1) como o "estatuto que rege, de um lado o respeito e a obediência que cidadão deve ao Estado e, de outro lado, a proteção e os serviços que o Estado deve dispensar, pelos meios possíveis, ao cidadão”.

Nagib Slaibi Filho (1995, p. 62) assevera que a cidadania "é o conjunto de obrigações e direitos que regem e definem a situação dos habitantes de um Estado-Nação".

A respeito do tema, José Afonso da Silva (1999, p. 11) afirma que:

A cidadania, assim considerada, consiste na consciência de pertinência à sociedade estatal como titular dos direitos fundamentais, da dignidade como pessoa humana, da integração participativa no processo do poder com a igual consciência de que essa situação subjetiva envolve também deveres de respeito à dignidade do outro, de contribuir para o aperfeiçoamento de todos. Essa cidadania é que requer providências estatais no sentido da satisfação de todos os direitos fundamentais em igualdade de condições. Se é certo que a promoção dos direitos sociais encontra, no plano das disponibilidades financeiras, notáveis limites, menos verdade não há de ser que, inclusive em épocas de recessão econômica, $o$ princípio da igualdade continua sendo um imperativo constitucional, que obriga a repartir também os efeitos negativos de todo período de crise.

Uma vez superada a ideia de que a cidadania esteja vinculada somente ao exercício de direitos políticos, é possível afirmar que o termo cidadania está ligado ao exercício dos direitos que são assegurados a todos os componentes do território estatal. Porém, deve-se ressaltar que também existem deveres atribuídos a cada um, inclusive ao próprio Estado, que podem e devem ser cobrados com eficácia pelos seus titulares, havendo assim a manutenção pacífica da relação entre o ente público e os particulares, bem como entre os particulares e eles próprios (FARAH, 2001, p. 4).

Com a ampliação do conceito de cidadania que emergiu com a promulgação da Constituição Federal de 1988, alguns diplomas jurídicos infraconstitucionais que disciplinavam a matéria restaram defasados.

Neste sentido, a legitimidade ativa para propositura da ação popular prevista no art. $5^{\circ}$, LXXIII, da Constituição Federal, disciplinada pelo $\S 3^{\circ}$, do art. $1^{\circ}$ da Lei 4.717/65, está sujeita a diversas compreensões, principalmente em face do conceito amplo ou estrito que venha a ser adotado em relação ao termo cidadão previsto no texto constitucional.

\section{LEGITIMIDADE ATIVA AMPLA PARA PROPOSITURA DA AÇÃO POPULAR}

A ação popular tem raízes no Direito Romano, e mesmo não havendo na Roma Antiga 
uma noção de Estado delineada como hodiernamente, prosperava entre os romanos um espírito cívico tão desenvolvido que possibilitava que uma pessoa que atendesse aos requisitos para ser considerada cidadã romana se dirigisse ao magistrado objetivando tutelar interesses coletivos (MANCUSO, 2011, p. 47).

No Brasil, a ação popular foi prevista pela primeira vez na Constituição de 1934, com o nome de ação anulatória, contemplada no item 38 do artigo 113 da Lei Maior. Muitas foram as vozes que criticaram a inserção da ação popular no texto constitucional, com destaque para Clóvis Beviláqua, que defendia ser o Ministério Público órgão competente para desempenhar a defesa de seu objeto, caminhando claramente no sentido contrário da pulverização da responsabilidade pela defesa do erário público entre os cidadãos, como previsto contemporaneamente (MANCUSO, 2011, p. 65-66).

Na Constituição Federal de 1988 a ação popular encontra-se prevista no art. 5º inciso LXXIII, nos seguintes termos (BRASIL, 1988):

Qualquer cidadão é parte legítima para propor ação popular que vise a anular ato lesivo ao patrimônio público ou de entidade de que o Estado participe, à moralidade administrativa, ao meio ambiente e ao patrimônio histórico e cultural, ficando o autor, salvo comprovada má-fé, isento de custas judiciais e do ônus da sucumbência.

A ação popular tem como objeto a anulação de ato lesivo ao patrimônio público ou de entidade de que o Estado participe, à moralidade administrativa, ao meio ambiente e ao patrimônio histórico cultural.

A garantia consubstanciada na ação popular, um dos instrumentos constitucionais brasileiros mais antigos de participação dos cidadãos nos negócios públicos, também é fundamental para a tutela jurisdicional dos interesses difusos, afinal, por meio do referido remédio constitucional não se postula a tutela de interesse pessoal, mas a proteção do patrimônio público e de interesses difusos (REMEDIO, 2018, p. 788-792).

Por sua vez, a Lei 4.717/65, que regula o exercício da ação popular, foi sancionada e publicada no ano de 1965, e de forma geral foi recepcionada pela Constitucional Federal de 1988.

Na doutrina, consoante Rosmar Antonni Rodrigues Cavalcanti de Alencar (2008, p. 31), a Lei 4.717/65 “não só foi recepcionada pela Constituição de 1967, como também pela Emenda Constitucional de 1969 e pela atual Constituição do Brasil, com suas alterações subsequentes no correr de mais de quarenta anos".

Na jurisprudência, ao julgar o Conflito de Competência n. 47.950-DF, o Superior Tribunal de Justiça sufragou o entendimento no sentido de que a Lei 4.717/65, que regula a ação popular, foi recepcionada pela Constituição Federal de 1988 (BRASIL, 2007).

Entretanto, há perceptível conflito a respeito dos significados dos termos "cidadania" e "cidadão", de um lado com base no Texto Constitucional de 1988 e, de outro lado, com fundamento na Lei $4.717 / 65$, especificamente no $\S 3^{\circ}$ do art. $1^{\circ}$ da Lei, ao estabelecer que "a prova da cidadania, 
para ingresso em juízo, será feita com o título eleitoral, ou com documento que a ele corresponda". Legalmente, para fins de ajuizamento da ação popular, a Lei 4.717/65 considera cidadão aquele que está no pleno gozo de seus direitos políticos e só, suplantando toda a evolução histórica que o conceito de cidadania sofreu, principalmente a partir da Revolução Francesa de 1789, desconsiderando, enfim, toda a construção sobre direitos civis e sociais ínsitos à Lei Maior Brasileira de 1988.

Este entendimento legal restritivo, de tratar a ação popular unicamente como dotada de natureza política, fez com que somente o cidadão eleitor ativo da comunidade pudesse ajuizar a ação.

No estudo em foco, conforme referido por José Afonso da Silva (2007, p. 153), a ausência de legitimatio ad causam para propositura da ação popular em relação aos não detentores de direitos políticos, é criticada por Ugo Rocco em face do conceito restrito atribuído ao termo cidadania, porém aceita por Chiovenda e pela jurisprudência dos tribunais brasileiros, inclusive dos tribunais superiores.

Alegitimação para propositura das ações judiciais em geral decorre da idoneidade conferida pela lei a determinados sujeitos para que possam conduzir ativa e passivamente o processo, e para fins de ajuizamento da ação popular a idoneidade do autor decorre de sua condição e qualidade enquanto membro da coletividade, cujo patrimônio é violado ou lesado (SILVA, 2007, p. 154).

Nos termos do $\S 3^{\circ}$ do art. $1^{\circ}$ da Lei $4.717 / 65$, para que tenha legitimidade ad causam o autor da ação popular deve necessariamente ser pessoa física, nacional, brasileiro nato ou naturalizado e ser cidadão eleitor, ou seja, ser titular de direitos políticos (VITTA, 2000, p. 40), o que cria uma disparidade entre o texto constitucional e a norma infraconstitucional, pois cidadão e eleitor são coisas distintas.

O que se busca impugnar é a vinculação limitativa do sentido do termo cidadão previsto na Constituição Federal, única e exclusivamente ao pleno gozo de direitos políticos previsto na Lei 4.717/65.

Afinal, a interpretação da palavra cidadania em conjunto com outras normas constitucionais, permite afirmar que o inciso LXXIII do art. $5^{\circ}$ da Constituição Federal teve como objetivo excluir apenas os estrangeiros não naturalizados e as pessoas jurídicas da legitimidade para propositura da ação popular (SILVA, 2007, p. 158).

As pessoas jurídicas, efetivamente, não possuem legitimidade para figurarem no polo ativo da ação popular, uma vez que não são cidadãs, orientação essa preconizada pela Súmula 365 do Supremo Tribunal Federal.

Ainda, há quem alimente a discussão sobre a interpretação do termo cidadão para fins de propositura da ação popular, tomando pela expressão "qualquer cidadão", de um lado, o nacional do país, aqui nascido ou naturalizado e, de outro lado, apenas o investido em direitos políticos.

Não obstante a riqueza da abordagem, há cristalina diferenciação entre os conceitos acima esposados, que sob o prisma da Constituição Brasileira repelem toda dúvida que possa emergir das argumentações apresentadas, inclusive em relação à nacionalidade. 
Na doutrina, conforme analisa Marcos Paulo Falcone Patullo (2009, p. 173):

A cidadania é, antes de tudo, fundamento da República Federativa do Brasil (art. $1^{\circ}$, II) e, portanto, abrange os direitos políticos (art. 14), os sociais (art. $6^{\circ}$ e seguintes), bem como relaciona-se diretamente com o princípio da dignidade da pessoa humana (art. $1^{\circ}$, III), assim como com todos os demais objetivos da República, constantes do art. $3^{\circ}$ da CF. Nesse diapasão, os direitos políticos seriam apenas uma dimensão da cidadania, sendo a nacionalidade um requisito apenas para a aquisição dessa dimensão, mas não para a cidadania em si. Consoante essa interpretação, a efetivação dos direitos de cidadania seria direito fundamental, já que dizem respeito à própria dignidade humana.

Como mencionado, a expressão "qualquer cidadão" pode ser entendida como a pessoa física, nacional, brasileiro nato ou naturalizado, e cidadão eleitor, ou seja, o titular de direitos políticos (VITTA, 2000, p. 40).

A Constituição Federal de 1988, ao dispor sobre direitos e garantias fundamentais, consagrou que todas as pessoas, possuidoras de direitos civis ou não, são titulares dos direitos ali elencados e alguns outros espalhados pelo texto constitucional, como o meio ambiente ecologicamente equilibrado prescrito no art. 225 e a gestão eficiente da coisa pública, o que abarca o patrimônio público e a moralidade administrativa.

Em relação ao disposto no art. 225 da Constituição Federal, embora não haja previsão expressa do meio ambiente ecologicamente equilibrado no capítulo dos direitos e garantias fundamentais, é incontroverso que se trata de um direito fundamental que pode ser tutelado pela ação popular.

Segundo Heraldo Garcia Vitta (2000, p. 41), há diversos dispositivos constitucionais que cuidam da proteção do meio ambiente, notadamente o art. 170, VI, sendo coerente afirmar que quando o objeto da ação popular for o meio ambiente, perde-se seu caráter político, razão pela qual qualquer pessoa poderá propor ação popular, pois não se cuida de direito político, o que poderia até mesmo ser estendido aos estrangeiros que residam no país.

$\mathrm{O}$ direito ao meio ambiente ecologicamente equilibrado encontra-se em perfeita simetria com direito à vida, e o direito à vida não se restringe apenas ao eleitor, mas engloba todos os brasileiros, independentemente de seu status político (VITTA, 2000, p. 41).

Assim, o alargamento do conceito de cidadania para fins de propositura da ação popular ambiental é tarefa menos árdua do que romper com o mesmo conceito para propositura de ações populares que tenham outros objetos a serem tutelados.

Porém, o que não se pode perder de vista é a ideia nuclear da discussão, ou seja, quem efetivamente é considerado cidadão para fins de ajuizamento da ação popular, independentemente do objeto protegido.

Nesse sentido, José da Silva Pacheco (2002, p. 568) trata da questão da legitimidade ativa de forma amplíssima, ao afirmar que o texto constitucional deve ser interpretado atendendo aos fins sociais a que se dirige e às exigências do bem comum, de modo que "todos os do povo, 
pessoas físicas e jurídicas e todas as instituições públicas ou privadas possam, diante de ato lesivo ao patrimônio público ou equiparado, propor ação popular destinada à invalidação daquele".

No entanto, a jurisprudência dos Tribunais brasileiros, inclusive dos Tribunais Superiores, é torrencial no sentido de que a condição de cidadão do autor popular, para ajuizar a ação, deve ser demonstrada por meio da apresentação de título de eleitor ou de documento equivalente.

Assim, conforme expressado pelo Ministro Castro Meira, do Superior Tribunal de Justiça, quando do julgamento do Recurso Especial n. 888.7656-SP, a legitimidade ativa para a propositura da ação popular está prevista no art. $5^{\circ}$, LXXIII, da CF, que assegura a qualquer cidadão, seja ele cidadão brasileiro nato ou naturalizado, inclusive aquele entre 16 e 21 anos, e, ainda, o português equiparado, no gozo dos seus direitos políticos, isto é, o eleitor, a possibilidade de propor ação popular (BRASIL, 2007).

É bem verdade que, em sentido contrário e de forma minoritária na jurisprudência, o Tribunal de Justiça de São Paulo, ao julgar a Apelação n. 9215624-79.2005.8.26.0000, apresentada em ação popular, acolheu parcialmente o recurso interposto por pessoa de naturalidade italiana, porém residente no Brasil em caráter permanente, para confirmar a possibilidade desta figurar no polo ativo de demanda que buscava impedir que a Municipalidade de Jaboticabal cortasse árvores seringueiras em determinada praça da Comarca, com fundamento no caput do art. $5^{\circ}$ e o art. 225, ambos da Constituição Federal (SÃO PAULO, 2011).

Apesar do entendimento jurisprudencial adotado no Brasil, a cidadania, alçada à categoria de fundamento da República com a promulgação da Constituição Federal de 1988, não pode restringir-se a direitos políticos para fins propositura da ação popular.

Gustavo de Medeiros Melo (2006, p. 19) apresenta três fundamentos que sustentam referida assertiva, um de natureza gramatical, outro de cunho sistemático e um terceiro de ordem histórica.

Sobre a natureza gramatical, o inciso LXXIII do art. $5^{\circ}$ da $\mathrm{CF} / 88$ afirma que qualquer cidadão é parte legítima para propor ação popular, sendo relevante mencionar que o dispositivo está inserido no título II da Constituição Federal, que corresponde aos direitos e garantias fundamentais que são inerentes a todos, que se inicia dizendo que todos são iguais perante a lei, sem distinção de qualquer natureza (MELO, 2006, p. 20-21). Por outro lado, há capítulo específico dedicado aos direitos políticos na Lei Maior, e neste capítulo nada foi disposto sobre a ação popular.

Sobre o fundamento de cunho sistemático, tem-se que a juntada do título de eleitor para comprovar a cidadania na ação popular é incompatível com a sistemática constitucional, sobressaindo a proteção do meio ambiente no âmbito constitucional que, conforme abordado na pesquisa, tem sua proteção a cargo de todas as pessoas, independentemente da prova de se estar no pleno gozo de direitos políticos (MELO, 2006, p. 24-25).

São bastante expressivas as normas constitucionais e infraconstitucionais que apontam para a ampliação do conceito do termo cidadania após a promulgação da Constituição Federal de 1988.

Nesse sentido, urge trazer a comento o art. $74, \S 2^{\circ}$, da Lei Maior, que legitima todo 
cidadão para, na forma da lei, denunciar irregularidades ou ilegalidades perante o Tribunal de Contas da União, o que, sem dúvida, não se limita ao detentor de direitos políticos.

Por sua vez, o art. 64 da ADCT/88, dispõe que a Imprensa Nacional e as demais gráficas da União, Estados, Distrito Federal e Municípios, da administração direta ou indireta, promoverão a edição popular do texto integral da Constituição, que será colocado à disposição das escolas e dos cartórios, dos sindicatos, dos quartéis, das igrejas e de outras instituições representativas da comunidade, gratuitamente, de modo que cada cidadão brasileiro possa receber um exemplar da Constituição do Brasil.

$\mathrm{Na}$ esfera infraconstitucional, o art. 72 da Lei 9.503/97 prevê que todo cidadão ou entidade civil tem o direito de solicitar, por escrito, aos órgãos ou entidades do Sistema Nacional de Trânsito, sinalização, fiscalização e implantação de equipamentos de segurança, assim como sugerir alterações em normas, legislação e outros assuntos pertinentes ao Código Nacional de Trânsito.

Da mesma forma, o art. $41, \S 1^{\circ}$, da Lei 8.666/93, estatui que qualquer cidadão é parte legítima para impugnar edital de licitação em face de irregularidade na aplicação da Lei de Licitações.

O terceiro fundamento repousa na feição histórica tomada pelo conceito de cidadania, pois a cidadania não abarca somente a prerrogativa de votar e ser votado, mas também confere a qualquer do povo a capacidade para fruir e fiscalizar os bens e serviços públicos (MELO, 2006, p. 27).

Entendimento contrário permitiria indevidamente concluir que, entre outros, mendigos, pessoas que vivem na periferia e pessoas que estejam com direitos políticos suspensos não seriam considerados cidadãos.

Portanto, a nova e mais ampla ideia de cidadania deve ser construída sob o influxo progressivo dos direitos fundamentais do homem, devendo o conceito de cidadão ditado pela Lei 4.717/65 ser modificado para estar em consonância com as premissas trazidas pelo Constituição Federal de 1988, para que o autor da ação popular, defensor da legalidade, moralidade administrativa e do meio ambiente, possa ser qualquer cidadão, independentemente de estar no pleno gozo de direitos políticos.

Dessa forma, o $\S 3^{\circ}$ do art. $1^{\circ}$ da Lei $4.717 / 65$, ao dispor que a prova da cidadania, para ingresso da ação popular em juízo, será feita com o título eleitoral ou com documento que a ele corresponda, limita o uso da ação apenas aos detentores de direitos políticos, inibindo assim a ampla utilização da garantia constitucional, padecendo, por isso, de vício de inconstitucionalidade, por ferir o disposto no inciso LXXIII do art. $5^{\circ}$ da Constituição Federal de 1988.

\section{CONCLUSÃO}

O Estado Brasileiro, após a promulgação da Constituição Federal de 1988, buscou deixar no passado os ideais que imperaram durante o Período Ditatorial iniciado em 1964, muitos dos 
quais cerceadores de direitos fundamentais.

Todavia, alguns institutos jurídicos do passado, inadequadamente interpretados, insistem em continuar surtindo efeitos no ordenamento jurídico brasileiro, motivo pelo qual insurgir-se contra eles é a melhor forma de se adequar à nova realidade social e de alavancar a implementação dos direitos e garantias fundamentais.

Entre os institutos, o conceito legal positivado pela Lei 4.717/65, relativamente ao termo cidadão para fins de propositura da ação popular, contraria a ideologia da Carta Magna de 1988, restringindo a aplicação do termo cidadão, constante do texto constitucional, exclusivamente aos detentores de direitos políticos, inibindo a ampla aplicação da garantia constitucional.

A ação popular foi instituída no âmbito da Constituição Federal de 1988 com a finalidade de legitimar qualquer cidadão para exercer a proteção contra ato lesivo ao patrimônio público ou de entidade de que o Estado participe, à moralidade administrativa, ao meio ambiente e ao patrimônio histórico e cultural (art. $5^{\circ}$, LXXIII).

Entretanto, o $\S 3^{\circ}$ do art. $1^{\circ}$ da Lei $4.717 / 65$, ao estatuir que a prova da cidadania, para ingresso em juízo, será feita com o título eleitoral ou com documento que a ele corresponda, limita o uso da ação popular apenas aos detentores de direitos políticos e inibe a utilização da garantia constitucional, padecendo, por isso, de vício de inconstitucionalidade.

Hádiversasnormas constitucionais querobustecemoentendimentodeinconstitucionalidade do referido art. $1^{\circ}, \S 3^{\circ}$, da Lei da Ação Popular, como ocorre em relação ao art. $72, \S 1^{\circ}$, da Constituição Federal, e no tocante ao art. 64 do Ato das Disposições Constitucionais Transitórias de 1988.

A amplitude do conceito da cidadania também é reconhecida por algumas disposições normativas infraconstitucionais posteriores à Lei 4.717/65 e à Constituição Federal de 1988, como se verifica com o art. 72 da Lei 9.503/97 e o art. 41, § $3^{\circ}$, da Lei 8.666/93.

A inconstitucionalidade do $\S 3^{\circ}$ do art. $1^{\circ}$ da Lei 4.717/65 também é claramente perceptível sob o enfoque da ação popular ambiental, pois, conforme o art. 225 da Constituição Federal, qualquer pessoa é legitimada para a defesa do meio ambiente, um dos objetos protegidos por meio da ação popular, sem qualquer necessidade de comprovar o gozo de direitos políticos com juntada de título de eleitor ou de documento equivalente.

Todavia, a jurisprudência brasileira dá raros sinais de ampliação em relação ao conceito restrito solidificado no âmbito dos Tribunais Brasileiros, com a preservação de seu atrelamento apenas aos direitos políticos.

É necessário que os Poderes Legislativo e Judiciário, dentro de suas prerrogativas, trabalhem em conjunto para romperem com o tradicional e restritivo conceito legal e jurisprudencial de cidadania, para que o cidadão possa figurar no polo passivo da ação popular independentemente do pleno gozo de direitos políticos, uma vez que a cidadania não está atrelada apenas aos direitos políticos, mas também aos direitos civis e sociais.

Tem-se, em conclusão, que restou comprovada a hipótese inicial, no sentido de que a Constituição Federal de 1988, ao prever a legitimidade ativa do cidadão para ajuizar a ação popular, 
não limita o sentido o termo cidadão apenas aos detentores de direitos políticos, ou seja, aos detentores de título de eleitor ou de documento equivalente, tendo o texto constitucional amplitude maior do que o previsto no $\S 3^{\circ}$ do art. $1^{\circ}$ da Lei $4.717 / 65$, sendo, assim, inconstitucional o referido dispositivo normativo infraconstitucional.

\section{REFERÊNCIAS}

ALENCAR, Rosmar Antonni Rodrigues Cavalcanti de. Ação popular: rumo à efetividade do processo coletivo. 2. ed. Porto Alegre: Núria Fabris Editora, 2008.

ARISTÓTELES. Política. São Paulo: Martin Claret, 2007.

ATALIBA, Geraldo. Ação popular na Constituição brasileira. Revista de Direito Público, São Paulo, n. 76, p. 110-121, out./dez. 1985.

BRASIL. [Constituição (1988)]. Constituição da República Federativa do Brasil. Brasília, DF: Presidência da República,1988. Disponível em: http://www.planalto.gov.br/ccivil_03/ Constituicao/Constituicao.htm. Acesso em: 12 abr. 2018.

BRASIL. Lei 4.717 de 29 de junho de 1965. Regula a ação popular. Brasília, DF: Presidência da República, 1965. Disponível em: http://www.planalto.gov.br/ccivil_03/leis/L4717.htm. Acesso em: 12 abr. 2018.

BRASIL. Superior Tribunal de Justiça (2. Turma). Recurso Especial 889.766/SP. Administrativo. Ação popular. Interesse de agir. Prova. Pericial. Desnecessidade. Matéria Constitucional. Relator: Min. Castro Meira, 04 de outubro de 2007. Diário da Justiça, Brasília, DF, p. 333, 18 out. 2007.

BRASIL. Superior Tribunal de Justiça. Conflito de Competência n. 47.950/DF. Relatora: Ministra Denise Arruda. Diário da Justiça: seção 1, Brasília, DF, p. 252, 7 maio 2007.

CAMPOS FILHO, Paulo Barbosa de. Da ação popular constitucional. São Paulo: Saraiva, 1968.

CORRALO, Giovani da Silva. Liberdade, igualdade e a qualidade da democracia: cotejo entre o IEU's INDES e o IDH. Revista Thesis Juris, São Paulo, v. 5, n. 2, p. 421-438, maio/ago. 2016.

DALLARI, Dalmo de Abreu. Elementos de teoria geral do Estado. 32. ed. São Paulo: Saraiva, 2013.

FARAH, Elias. Cidadania. São Paulo: Juarez de Oliveira, 2001.

FIGUEIRA, Divalte Garcia. História. São Paulo: Ática, 2001. (Série novo ensino médio, v. único).

FUNARI, Pedro Paulo. Grécia e Roma. São Paulo: Contexto, 2002.

MANCUSO, Rodolfo de Camargo. Ação popular: proteção do erário, do patrimônio público, da moralidade administrativa e do meio ambiente. 7. ed. São Paulo: Revista dos Tribunais, 2011.

MARKY, Thomas. Curso elementar de direito romano. 8. ed. São Paulo: Saraiva, 1995. 
MARSHALL, Thomas Humphrey. Cidadania e classe social. In: PORTO, Walter Costa (coord.). Cidadania e classe social. Brasília: Fundação Projeto Rondon, 1988. p. 9.

MELO, Gustavo de Medeiros. A legitimidade ativa na ação popular: relendo o conceito de cidadão quarenta anos depois. In: GOMES JÚNIOR, Luiz Manoel; SANTOS FILHO, Ronaldo Fenelon (org.). Ação popular: aspectos relevantes e controvertidos. São Paulo: RCS, 2006. p. 163-206.

PACHECO, José da Silva. O mandado de segurança e outras ações constitucionais típicas. 4. ed. São Paulo: Revista dos Tribunais, 2002.

PATULLO, Marcos Paulo Falcone. O liberalismo igualitário de Ronald Dworkin e a cidadania na Constituição Federal de 1988. Revista da APMP, São Paulo, v. 2, p. 171-184, jan./jun. 2009.

REMEDIO, José Antônio. Direito administrativo. 3. ed. São Paulo: Verbatim, 2018.

SAMPAIO, Maria Cristina Hennes. Democracia cidadania e produção de um espaço público democrático em tempos de globalização: práticas discursivas entre estado-sociedade no movimento grevista da educação em Pernambuco (1987-1990). São Paulo: Serviço de Comunicação Social, FFLCH/USP, 2008.

SÃO PAULO (Estado). Tribunal de Justiça. Apelação n. 9215624-79.2005.8.26.0000. Relator: Antônio Celso Aguilar Cortez, 30 de agosto de 2011. Disponível em: https://tj-sp.jusbrasil.com. br/jurisprudencia/20355224/apelacao-apl-9215624792005826-sp-9215624-7920058260000/ inteiro-teor-104922305?ref=juris-tabs. Acesso em: 12 abr. 2018.

SILVA, José Afonso da. Ação popular constitucional. 2. ed. São Paulo: Malheiros, 2007.

SILVA, José Afonso da. Acesso à justiça e cidadania. Revista de Direito Administrativo, Rio de Janeiro, v. 216, p. 9-23, abr./jun. 1999.

SIQUEIRA JÚNIOR, Paulo Hamilton; OLIVEIRA, Michel Augusto Machado. Direitos humanos e cidadania. 2. ed. São Paulo: Revista dos Tribunais, 2009.

SLAIBI FILHO, Nagib. Ação popular mandatória. Rio de Janeiro: Forense, 1995.

VITTA, Heraldo Garcia. O meio ambiente e a ação popular. São Paulo: Saraiva, 2000.

Como citar: REMEDIO, José Antônio; ARANJUES, Gabriel Silva. A amplitude do conceito de cidadania para efeito de propositura da ação popular. Revista do Direito Público, Londrina, v. 14, n. 3, p. 184-200, dez. 2019. DOI: 10.5433/24157-108104-1.2019v14n3p. 184. ISSN: 1980-511X

Recebido em: 22.08.2018

Aprovado em: 13.02.2019 